\title{
Motivation and Attitude of Students on Physics Subject in the Middle School in Indonesia
}

\author{
Astalini $^{1}$, Darmaji ${ }^{1}$, H. Pathoni ${ }^{1}$, W. Kurniawan ${ }^{1}$, Jufrida $^{1}$, Dwi Agus Kurniawan ${ }^{1} \&$ R. Perdana ${ }^{1}$ \\ ${ }^{1}$ Faculty Of Teaching and Education, Universitas Jambi, Jambi, Indonesia \\ Correspondence: Dwi Agus Kurniawan, Faculty Of Teaching and Education, Universitas Jambi, Jambi, Indonesia.
}

Received: February 12, 2019

Accepted: April 15, $2019 \quad$ Online Published: August 29, 2019

doi:10.5539/ies.v12n9p15

URL: https://doi.org/10.5539/ies.v12n9p15

\begin{abstract}
Purpose: This study aims to determine whether there is a relationship between motivation and attitudes of students towards physics subjects in high school. Method: The type of research used is quantitative descriptive with correlational design. The data used by researchers were in the form of questionnaires/motivational questionnaires and attitudes with a total of 54 statements for attitude questionnaires and 23 statements for motivational questionnaires using liker scale 5. Data Analysis: using descriptive and inferential statistics. Findings: the results of this study researchers get good results and enough attitudes towards physics investigation, adoption of scientific attitudes pleasure in learning physics, interested in participating in physics learning activities, believe that he has the ability of physics, and enjoy working on physics tasks good enough, this is in accordance with the analysis of the relationship that has been done, that there is a relationship between motivation and student attitudes toward physics subjects, with details, at level 1 the correlation coefficient is 0.318 , then at level 2 is 0.862 and at level 3 is -0.56 , at level 1 has a low positive relationship, level 2 has a strong positive relationship, while at level 3 has a moderate negative relationship.
\end{abstract}

Keywords: attitude, motivation, physics subject

\section{Introduction}

Education is a very important activity, with the education of humans can change behavior and knowledge for the better (Astalini et al., 2019; Kurniawan, Astalini, \& Anggraini, 2018). Education is a framework process in order to influence students to be able to adjust as well as possible with their environment and by doing so will cause changes in themselves that enable them to function in social life (Higgins \& Kruglanski, 2000). In education it consists of several levels, one of them is the High School level (Astalini et al., 2018). High school is the level of education that must be taken before continuing education to a higher level. In the level of high school education studying various sciences one of the sciences studied is physics. Physics is the result of human activities in the form of knowledge, ideas, and concepts that are organized about the environment obtained from a series of experiences through a scientific process (Prihatiningtyas et al., 2013).

The attitude of students usually affects the results of the students' achievement. This is also explained by Rijal and Bachtiar (2015) students who have a positive attitude towards certain lessons is more diligent in learning so as to achieve satisfactory results. In addition, attitude of teachers also exerts influences on the formation of students' personalities (Zhang \& Han, 2008). Conversely, students who have a negative attitude towards learning will not be eager to learn so the results are less satisfying. This negative attitude itself is an attitude that prevents these students from learning such as: playing gadgets when learning is taking place, playing with an adjoining friend, sleeping while learning and even skipping school while positive attitudes can be interpreted as attitudes that support students to learn like the lesson, and is present in learning. This is explained by Osman, Iksan, and Halim (2007), there are two perceptions or attitudes of students towards physics as one in the science family, namely positive attitudes and negative traits where both attitudes greatly influence the success of a student in learning science, especially physics. Therefore a study of student attitudes or perceptions of science needs to be done so that later the results can be known.

Student learning outcomes will be optimal if the student is motivated in learning. This is also explained by (Higgins \& Kruglanski, 2000) that a good motivation in learning will show good results, so if a child knows that a series of good learning intentions is done well, he will achieve a brilliant achievement. Motivation in learning can influence how the process and learning outcomes of a student (Santoso, 2013). According to Sudibyo, Jatmiko, 
and Widodo (2016) motivated behavior is a behavior that is full of energy, directed, and enduring. Furthermore according to Astalini et al. (2019), learning media can generate motivation, learning stimuli, and bring psychological influence to students, so students become more aware of the material being studied.

Attitudes towards investigations in physics contain students' perceptions or views of ways or actions in solving physics problems. The most important competence that physics education students should have is skill competence, by having skills supported by scientific knowledge and students' abilities of a scientific approach; physics students can develop an understanding of scientific concepts (Darmaji et al., 2018). In studying physics, students usually carry out investigations, both in class and in the lab, examples of observing and concluding information, classifying data, predicting, measuring, and questioning, interpreting and analyzing data. Although it covers traditional science processes, inquiry also refers to the incorporation of these processes with scientific knowledge and reasoning and critical thinking (Lederman et al., 2013). Students develop confidence during school that to get conclusions it is necessary to have step by step that must be followed in a scientific method; this is how scientists produce new knowledge (Moeed, 2013). The form of physical inquiry in class can be seen through the steps of how students in answering a problem, namely by observing an illustrated picture of an event, collecting and classifying known data, and interpreting and analyzing it using an appropriate formula for problem solving. When in the laboratory, investigating physics by students can be seen from how students obtain experimental data, namely by observing and deciding which tools need to be used, making hypotheses, taking / collecting data based on appropriate procedures to prove hypotheses, measuring objects, analyzing experimental data and then concluding results and compare data with theory.

The adoption of scientific attitudes includes scientific attitudes needed in studying physics. Several factors influence student attitudes toward science such as gender, personality, structural variables and curriculum variables (Trumper, 2006). The scientific attitude has 3 main components, namely beliefs, feelings and actions (Mukhopadhyay, 2014). Scientific attitude will greatly help the course of a more structured learning process so that the knowledge gained is more organized and conceptual. Adoption of scientific attitudes will encourage students to use scientific methods or methods in problem solving both in the learning environment and in students' daily lives. For example, in conducting experiments, students hypothesize based on beliefs that they think will occur. From this belief arises the feeling to prove the truth and then the student take the necessary actions to prove the hypothesis that the student believes. When learning in class, the application of scientific attitudes can also be seen from the attitudes of students who want to prove the concept of physics which is believed by decreasing the formula and its application in practice questions. This shows that attitudes toward physics also relate to adopting scientific attitudes as a way of thinking students.

The attitude of students who are positive towards physics will have a sense of pleasure when the learning process takes place. The fun of students when learning will have an intensive character in learning (Manasia, 2015). Students who have the pleasure of learning physics will influence the results of learning physics. The fun of students in learning can improve learning outcomes which will provide predictive effects in science learning (Ainley, 2011). Students who love learning physics will have a high curiosity about physics. This high curiosity can be influenced by several factors, one of which is a comfortable classroom. Maharaj-Sharma and Sharma (2017) comfortable classrooms can grow students 'skills and increase students' enjoyment of learning physics.

Students' interest in participating in physics learning activities is influenced by two factors, namely internal factors (intrinsic motivation), and external factors (extrinsic motivation). Intrinsic motivation is motivation that is included in learning situations and often also called pure motivation (Higgins \& Kruglanski, 2000). For example, students have their own willingness to learn physics, be able and concentrate while studying physics (Higgins \& Kruglanski, 2000). Extrinsic motivation is motivation caused by factors from outside the learning situation (Higgins \& Kruglanski, 2000). Like getting a prize, getting good grades (Higgins \& Kruglanski, 2000). For this reason, the teacher must be able to motivate students to be interested in learning.

With the interest of students in participating in physics learning, it will give them confidence that they have abilities in physics. To have ability especially in physics or science, students must do something related to science or physics (Dewati, 2015). Therefore, by having this ability students are more motivated in learning. Students who are highly motivated in learning make it possible to get high learning outcomes too, meaning that the higher the motivation, the more intensity of effort and effort is made, the higher the learning achievement he gets (Hamdu \& Agustina, 2011).

When students have self-confidence that he has the ability to learn physics, then he will enjoy working on his assignments, and can also be influenced by the students' attitude to learning physics that is owned by the student. That links with successful learning and self-perception of increased well-being (Lucardie, 2014). Students who 
have their own willingness to learn physics generated from within themselves (Hamdu \& Agustina, 2011). When students enjoy and believe in themselves, it is these things that can get the results of their learning.

The success of the learning process can be seen from the learning outcomes where the learning outcomes are influenced by good attitudes and motivations of students. The students, who have a negative attitude towards physics, have a lack of motivation for class engagement; and also students who have positive attitudes towards physics, have motivation for class engagement (Guido, 2013).

The purpose of this study was to determine the relationship between motivation and attitudes of students towards physics learning in high school. The attitude indicators include Attitudes towards Investigation in Physics, Adoption of Scientific Attitudes, and Fun in Learning Physics, while for indicators of motivation include Interested in participating in physics learning activities, Believing that he has the ability of physics, and enjoying while doing physics tasks. In this study the research questions are as follows:

1) How to describe attitudes toward investigation in physics learning?

2) How to describe the adoption of students' scientific attitudes in learning physics?

3) How to describe the attitude of student learning pleasure in learning physics?

4) How to describe students' motivation to be interested in participating in physics learning?

5) How to describe the motivation of students who have the ability to learn physics?

6) How to describe the motivation of students who enjoy while doing tasks in learning physics?

7) What is the relationship between students' motivation and attitudes towards physics subjects?

The findings of this study can contribute to increasing students' motivation and attitudes towards physics learning. This research is very important, especially at the high school level because motivation and attitudes can influence learning outcomes.

\section{Method}

\section{Study Methodology:}

This study used the descriptive and inferential this study:

\subsection{Research Design}

The research design used in this study is the Associative Quantitative research method with a correlational research design. Associative quantitative research is research that aims to determine the relationship between two or more variables (Cohen, Manion, \& Morrison, 2007). Because the research is associative research, the researcher took a correlational research design. According to Creswell (2012), "Correlational Design is a procedure in quantitative research that is used by researchers to measure the degree of association (relationship) between two or more variables using statistical analysis correlation procedures".

\subsection{Research Sample}

The sample that the researchers used was all students of Senior High School in 5, 6, 8 Batanghari which numbered 268 students, with male students numbering 121 and female students totaling 147 students. In this study the researcher used total sampling technique. Total sampling is a technique of determining samples that uses all populations as a sample (Creswell, 2012).

\subsection{Instrument and Procedure}

In this study, the study used two questionnaire instruments where, in the attitude questionnaire adopted from the Rio Darmawangsa (2018) study which had 54 valid statements with 7 indicators which had a Cronbach alpha reliability value of 0.9 and for the motivational questionnaire adapted from Sudibyo, Jatmiko, and Widodo (2016) has 23 valid statements with 12 indicators that have Cronbach alpha reliability value of 0.86 , in this study, researchers used 3 indicators using a Likert scale 5 (five) for positive statements Strongly Disagree having a score of 1, Disagree having a score of 2, Neutral having score 3, Agree has a score of 4 and Strongly Agree 5. For negative statements Strongly Disagree has a score of 5, Disagree has a score of 4, Neutral has a score of 3, Agree has a score of 2 and Strongly Agree has a score of 1)

\subsection{Data Analysis}

The data in this study used quantitative analysis data using the SPSS program to look for descriptive and inferential statistics. Descriptive statistics are a description or presentation of large amounts of data, in this case in the form of summary frequencies, for example mode, mean, median, minimum, maximum and standard deviation (Cohen, 
Manion, \& Morrison, 2007). Statistical inference from mathematical procedures for using probabilities and information about samples to draw conclusion about the population from which the sample is presumably was drawn (M. Gall, J. Gall, \& Borg, 2003). In this study there is a prerequisite test and hypothesis test, the prerequisite test used is the normality test and linearity test, and for testing the hypothesis using product moment correlation.

\section{Results}

\subsection{Attitudes Towards Investigation in Physics}

In the attitude towards inquiry in physics, we can see the results of the questionnaire that has been distributed, with the results as in the Table 1 below.

Table 1. Attitude towards investigation in physics in Indonesia

\begin{tabular}{|c|c|c|c|c|c|c|c|}
\hline \multicolumn{3}{|l|}{ Category } & \multirow{2}{*}{ Mean } & \multirow{2}{*}{ Median } & \multirow{2}{*}{ Min } & \multirow{2}{*}{ Max } & \multirow{2}{*}{$\%$} \\
\hline Interval & Attitude & Total & & & & & \\
\hline $9.0-16.2$ & Very Not Good & 0 & & & & & 0 \\
\hline $16.3-23.4$ & Not Good & 14 & & & & & 5.2 \\
\hline $23.5-30.6$ & Enough & 137 & 30.01 & 30 & 21 & 44 & 51.3 \\
\hline $30.7-37.8$ & Good & 101 & & & & & 37.6 \\
\hline $37.9-45.0$ & Very Good & 16 & & & & & 5.9 \\
\hline TOTAL & & 268 & & & & & 100 \\
\hline
\end{tabular}

In Table 1, it was obtained from 268 respondents who came from high school and were processed using the SPSS program, with the results processed using the SPSS application, it was obtained for attitudinal indicators of investigations in physics to have a sufficient category of $51.3 \%$ for a total of 137 of 268 students, good at $37.6 \%$ for a total of 101 out of 268 students. Very Good at $5.9 \%$ for a total of 16 out of 268 students and Not Good at 5.2\% for a total of 14 out of 268 students. Of 268 students the Mean 30.01, Maximum Value 44, Minimum Value 21, and Median 30.

\subsection{Adoption of Scientific Attitudes}

In this scientific attitude adoption, we can see the results of the questionnaire that has been distributed, with the results as in the Table 2 below.

Table 2. Adoption of scientific attitudes in Indonesia

\begin{tabular}{|c|c|c|c|c|c|c|c|}
\hline \multicolumn{3}{|l|}{ Category } & \multirow{2}{*}{ Mean } & \multirow{2}{*}{ Median } & \multirow{2}{*}{ Min } & \multirow{2}{*}{ Max } & \multirow{2}{*}{$\%$} \\
\hline Interval & Attitude & Total & & & & & \\
\hline $7.0-12.6$ & Very Not Good & 0 & & & & & 0 \\
\hline $12.7-18.2$ & Not Good & 12 & & & & & 4.5 \\
\hline $18.3-23.8$ & Enough & 51 & 26.54 & 27 & 16 & 35 & 19.0 \\
\hline $23.9-29.4$ & Good & 154 & & & & & 57.5 \\
\hline $29.5-35.0$ & Very Good & 51 & & & & & 19.0 \\
\hline TOTAL & & 268 & & & & & 100 \\
\hline
\end{tabular}

In Table 2, it was obtained from 268 respondents from high school and had been processed using the SPSS program using the SPSS application, it was found that the indicator of adoption of scientific attitudes had a Good category of $57.5 \%$ for a total of 154 of 268 students, Very Good at $19.0 \%$ for a total of 51 of 268 students. Enough of $19.0 \%$ for a total of 51 out of 268 students and Not Good at $4.5 \%$ for a total of 12 out of 268 students. with 268 students the results of Mean 26.54, Maximum Value 35, Minimum Value 16, and Median 27.

\subsection{Fun in Learning Physics}

The results of the questionnaire about learning physics can be seen in the Table 3 below. 
Table 3. Fun in learning physics in Indonesia

\begin{tabular}{|c|c|c|c|c|c|c|c|}
\hline \multicolumn{3}{|l|}{ Category } & \multirow{2}{*}{ Mean } & \multirow{2}{*}{ Mode } & \multirow{2}{*}{ Min } & \multirow{2}{*}{ Max } & \multirow{2}{*}{$\%$} \\
\hline Interval & Attitude & Total & & & & & \\
\hline $10.0-18.0$ & Very Not Good & 6 & & & & & 2.3 \\
\hline $18.1-26.0$ & Not Good & 29 & & & & & 10.8 \\
\hline $26.1-34.0$ & Enough & 116 & 33.0 & 30 & 12 & 50 & 43.2 \\
\hline $34.1-42.0$ & Good & 81 & & & & & 30.3 \\
\hline $42.1-50.0$ & Very Good & 36 & & & & & 13.4 \\
\hline TOTAL & & 268 & & & & & 100 \\
\hline
\end{tabular}

Table 3 shows that 268 respondents from high school have been processed using the SPSS program, it was found that the indicators of pleasure in learning physics had a sufficient category of $43.2 \%$ for a total of 116 out of 268 students, good by $30.3 \%$ for a total of 81 of 268 students, Not good at $10.8 \%$ for a total of 29 out of 268 students and Very Good at 13.4\% for a total of 36 out of 268 students, and Very Not Good 2.3\% for a total of 6 out of 268 students. With 268 students the results of the Mean 33.0, Maximum Value 55, and Minimum Value 12, Median 33.

\subsection{Interested in Following Physics Learning Activities}

The results of the questionnaire for interest in participating in physics learning activities can be seen in the Table 4 below.

Table 4. Interested in participating in physics learning activities in Indonesia

\begin{tabular}{|c|c|c|c|c|c|c|c|}
\hline \multicolumn{3}{|l|}{ Category } & \multirow{2}{*}{ Mean } & \multirow{2}{*}{ Median } & \multirow{2}{*}{ Min } & \multirow{2}{*}{ Max } & \multirow{2}{*}{$\%$} \\
\hline Interval & Motivation & Total & & & & & \\
\hline $5.0-9.0$ & Very Not Good & 7 & & & & & 2.6 \\
\hline $9.1-13.0$ & Not Good & 27 & & & & & 10.1 \\
\hline $13.1-17.0$ & Enough & 117 & 17.08 & 17 & 7 & 25 & 43.6 \\
\hline $17.1-20.0$ & Good & 92 & & & & & 34.3 \\
\hline $21.1-25.0$ & Very Good & 25 & & & & & 9.4 \\
\hline TOTAL & & 268 & & & & & 100 \\
\hline
\end{tabular}

Table 4 shows that 268 respondents from high school have been processed using the SPSS program, it was found that the indicators of pleasure in learning physics had a sufficient category of $43.6 \%$ for a total of 117 out of 268 students, good at $34.3 \%$ for a total of 92 out of 268 students. Not Good at $10.1 \%$ for a total of 27 out of 268 students and Very Good at $9.4 \%$ for a total of 25 out of 268 students, and Very Not Good $2.6 \%$ for a total of 7 out of 268 students with 268 respondents the results of the Mean 17.08, Maximum Value 25, and Minimum Value 7, Median 17.

\subsection{Believing that He Has the Ability About Physics}

The results of the questionnaire from believing that they have abilities about physics can be seen in the table below.

Table 5. Believe that he has the ability about physics in Indonesia

\begin{tabular}{|c|c|c|c|c|c|c|c|}
\hline \multicolumn{3}{|l|}{ Category } & \multirow{2}{*}{ Mean } & \multirow{2}{*}{ Median } & \multirow{2}{*}{ Min } & \multirow{2}{*}{ Max } & \multirow{2}{*}{$\%$} \\
\hline Interval & Motivation & Total & & & & & \\
\hline $2.0-3.6$ & Very Not Good & 7 & & & & & 2.6 \\
\hline $3.7-3.4$ & Not Good & 35 & & & & & 13.1 \\
\hline $5.3-6.8$ & Enough & 85 & 6.62 & 7 & 2 & 10 & 31.7 \\
\hline $6.9-8.4$ & Good & 112 & & & & & 41.8 \\
\hline $8.5-10.0$ & Very Good & 29 & & & & & 10.8 \\
\hline TOTAL & & 268 & & & & & 100 \\
\hline
\end{tabular}

Table 5 shows that 268 respondents from high school were processed using the SPSS program, it was obtained for the indicator to believe that he had the ability about physics to have a Good category of $41.8 \%$ for a total of 112 out of 268 students, Enough of $31.7 \%$ for a total of 85 out of 268 students. Not Good at $13.1 \%$ for a total of 35 out of 
268 students and Very Good at $10.8 \%$ for a total of 29 out of 268 students, and Very Not Good $2.6 \%$ for a total of 7 out of 268 students. With 268 respondents the results of Mean 6.62, Maximum Value 10, Minimum Value 2, and Median 7.

\subsection{Enjoy When Working on Physics Tasks}

The results of the questionnaire to enjoy while working on physics tasks can be seen in the tab below.

Table 6. Enjoy while working on physics tasks in Indonesia

\begin{tabular}{|c|c|c|c|c|c|c|c|}
\hline \multicolumn{3}{|l|}{ Category } & \multirow{2}{*}{ Mean } & \multirow{2}{*}{ Median } & \multirow{2}{*}{ Min } & \multirow{2}{*}{ Max } & \multirow{2}{*}{$\%$} \\
\hline Interval & Motivation & Total & & & & & \\
\hline $1.0-1.8$ & Very Not Good & 19 & & & & & 7.1 \\
\hline $1.9-2.6$ & Not Good & 12 & & & & & 4.5 \\
\hline $2.7-3.4$ & Enough & 104 & 3.47 & 3 & 1 & 5 & 38.8 \\
\hline $3.5-4.2$ & Good & 90 & & & & & 33.6 \\
\hline $4.3-5.0$ & Very Good & 43 & & & & & 16.0 \\
\hline TOTAL & & 268 & & & & & 100 \\
\hline
\end{tabular}

Table 6 shows that 268 respondents from high school have been processed using the SPSS program, From the results of table 6 that has been processed using the SPSS application, it was found that the indicators of pleasure in learning physics had a sufficient category of $38.8 \%$ for a total of 104 out of 268 students, good at $33.6 \%$ for a total of 90 out of 268 students. Very good at $16.0 \%$ for a total of 43 out of 268 students and Very Bad at $7.1 \%$ for a total of 19 out of 268 students, and Not Good $4.5 \%$ for a total of 12 students from 268 students. With 268 respondents the results of mean 3.47 , maximum value 5 , minimum value 1 , and median 3 .

\subsection{Assumption Test}

In this study, researchers used two conditions that were used as assumption tests or prerequisite tests, namely normality test and linearity test. To use the parametric hypothesis test, the data obtained must be normal and also linear. If the data is normal and has a linear variant, parametric statistics are used (M. Gall, J. Gall, \& Borg, 2003).

Normality test:

The results of the assumption test for normality tests on attitudes can be seen in Table 7 and Table. 8 for motivation.

Table 7. Output of Attitude Normality Test

\begin{tabular}{|c|c|c|c|c|}
\hline \multicolumn{5}{|c|}{ One-Sample Kolmogorov-Smirnov Test } \\
\hline & & $\mathrm{S} 10$ & S11 & $\mathrm{S} 12$ \\
\hline $\mathrm{N}$ & & 80 & 100 & 88 \\
\hline \multirow{3}{*}{ Normal Parameters ${ }^{\mathrm{a}, \mathrm{b}}$} & Mean & 189.86 & 178.18 & 176.93 \\
\hline & Std. Deviation & 23.929 & 27.597 & 14.696 \\
\hline & Absolute & .120 & .091 & .087 \\
\hline \multirow[t]{2}{*}{ Most Extreme Differences } & Positive & .120 & .070 & .077 \\
\hline & Negative & -.066 & -.091 & -.087 \\
\hline Kolmogorov-Smirnov Z & & .852 & .702 & .666 \\
\hline Asymp. Sig. (2-tailed) & & .463 & .708 & .767 \\
\hline
\end{tabular}

From the results of the table output, S10 is attitude in class $10, \mathrm{~S} 11$ is attitude in class 11 and S12 is attitude in class 12. We can see the value of Asymp. Sig (2-tailed) is greater than 0.05 , meaning that the data is normally distributed. If the sig value is $>0.05$, the data is declared to be normally distributed (M. Gall, J. Gall, \& Borg, 2003). 
Table 8. Output of motivation normality test

\begin{tabular}{|c|c|c|c|c|}
\hline \multicolumn{5}{|c|}{ One-Sample Kolmogorov-Smirnov Test } \\
\hline & & M10 & M11 & M12 \\
\hline $\mathrm{N}$ & & 80 & 100 & 88 \\
\hline \multirow{3}{*}{ Normal Parameters ${ }^{\mathrm{a}, \mathrm{b}}$} & Mean & 81.84 & 81.20 & 81.72 \\
\hline & Std. Deviation & 11.018 & 15.920 & 10.244 \\
\hline & Absolute & .162 & .070 & .139 \\
\hline \multirow[t]{2}{*}{ Most Extreme Differences } & Positive & .162 & .056 & .139 \\
\hline & Negative & -.107 & -.070 & -.056 \\
\hline Kolmogorov-Smirnov Z & & 1.148 & .541 & 1.061 \\
\hline Asymp. Sig. (2-tailed) & & .144 & .932 & .210 \\
\hline
\end{tabular}

From the results of the table output, M10 is the motivation of class 10, M11 is motivation in class 11 and M12 is motivation in class 12 . And we can see that the value of Asymp Sig is large from 0.05, it means the data is normally distributed. If the sig value is $>0.05$ then the data is declared to be normally distributed (M. Gall, J. Gall, \& Borg, 2003).

\section{Linearity Test:}

The assumption test results for linearity tests in class 10 can be seen in the Table 9.

Table 9. Class 10 linear test outputs

\begin{tabular}{lllllll}
\hline ANOVA $^{\mathrm{a}}$ & \multicolumn{7}{l}{} \\
\hline Model & & Sum of Squares & Df & Mean Square & F & Sig. \\
& Regression & 2838.072 & 1 & 2838.072 & 5.402 & $.024^{\text {b }}$ \\
1 & Residual & 25219.948 & 48 & 525.416 & & \\
& Total & 28058.020 & 79 & & & \\
\hline
\end{tabular}

From the Table 9, we can see that the sig value of 0.024 is smaller than 0.05 , which means the data for class 10 between attitude and motivation are linear. If the value of $\operatorname{sig}<0.05$ then the data is significant or linear (M. Gall, J. Gall, \& Borg, 2003).

The results of the assumption test for linearity tests in class 11 can be seen in the Table 10.

Table 10. Class 11 linear test outputs

\begin{tabular}{lllllll}
\hline ANOVA $^{\mathrm{a}}$ & & & & & \\
\hline Model & & Sum of Squares & Df & Mean Square & $\mathrm{F}$ & Sig. \\
& Regression & 33359.411 & 1 & 33359.411 & 167.178 & $.000^{\mathrm{b}}$ \\
1 & Residual & 11573.572 & 58 & 199.544 & & \\
& Total & 44932.983 & 99 & & & \\
\hline
\end{tabular}

From the Table 10, we can see that the sig value is 0.000 , which is $<0.05$, meaning that the data between attitude and motivation in class 11 are linear. If the value of sig $<0.05$ then the data is significant or linear (M. Gall, J. Gall, $\&$ Borg, 2003).

The results of the assumption test for linearity tests in class 12 can be seen in the Table 11 .

Table 11. Class 12 linear test outputs

\begin{tabular}{lllllll}
\hline ANOVA $^{\mathrm{a}}$ & \multicolumn{7}{l}{} \\
\hline Model & & Sum of Squares & Df & Mean Square & F & Sig. \\
& Regression & 911.421 & 1 & 911.421 & 4.478 & $.039^{\mathrm{b}}$ \\
1 & Residual & 11398.303 & 56 & 203.541 & & \\
& Total & 12309.724 & 87 & & & \\
\hline
\end{tabular}


From the Table 11, we can see that the sig value in class 12 is 0.039 , which is $<0.05$, meaning that the data between attitude and motivation in class 12 are linear. If the value of $\operatorname{sig}<0.05$ then the data is significant or linear (M. Gall, J. Gall, \& Borg, 2003)

\subsection{Hypothesis Testing}

The hypothesis test used by the researcher is the moment product correlation, because the data the researcher gets is normally and linearly distributed, so the moment product correlation is used. Where, moment product correlation has conditions, that is if the value of sig $<0.05$, then there is a relationship between motivation and attitudes of students. This is in accordance with (M. Gall, J. Gall, \& Borg, 2003) if the sig / probability value is $<0.05$, then there is a relationship.

\subsection{Relationship Between Motivation and Attitudes Towards Physics Subjects}

The results of hypothesis testing for class X, XI, and XII between motivation and attitudes can be seen in the Table 12.

Table 12. Test output hypotheses in class X, XI, and XII

\begin{tabular}{|c|c|c|c|c|c|c|c|}
\hline \multicolumn{8}{|c|}{ Correlation } \\
\hline & & Motivation_class10 & Attitude_class 10 & Motivation_class11 & Attitude_class11 & Motivation_class12 & Attitude_class 12 \\
\hline \multirow{3}{*}{ Motivation_class } & $\begin{array}{c}\text { Pearson } \\
\text { Correlation }\end{array}$ & 1 & $.318^{*}$ & 1 & $.862^{* * *}$ & 1 & $-.566^{* *}$ \\
\hline & Sig. (2-tailed) & & .024 & & .000 & & .000 \\
\hline & $\mathrm{N}$ & 80 & 80 & 100 & 100 & 88 & 88 \\
\hline \multirow{3}{*}{ Attitude_class } & $\begin{array}{c}\text { Pearson } \\
\text { Correlation }\end{array}$ & $.318^{*}$ & 1 & $.862^{* *}$ & 1 & $-.566^{* *}$ & 1 \\
\hline & Sig. (2-tailed) & .024 & & .000 & & .000 & \\
\hline & $\mathrm{N}$ & 80 & 80 & 100 & 100 & 88 & 88 \\
\hline
\end{tabular}

From the Table 12, we can see that the sig value is 0.24 small from 0.05 , it can be concluded that there is a relationship between motivation and attitudes of students in class $X$ with $r$ value of 0.3 and positive. If the value of sig $<0.05$ then there is a relationship (M. Gall, J. Gall, \& Borg, 2003). It can be seen that the sig value is 0,000 small than 0.05 , so we can conclude that there is a relationship between motivation and attitudes of students in class XI with a $r$ value of 0.8 and positive. If the value of sig $<0.05$ then there is a relationship (M. Gall, J. Gall, \& Borg, 2003). It can be seen that the sig value is 0.000 small from 0.05 , and we can conclude that there is a relationship between motivation and attitudes of students in class XII with a value of $\mathrm{r}-0.56$ and negative. If the value of sig $<0.05$ then there is a relationship (M. Gall, J. Gall, \& Borg, 2003).

\section{Discussion}

Based on the results of questionnaire data management on attitudinal indicators in the investigation of physics in high school, the dominant students were in the category of enough with a percentage of $51.3 \%$ of the total 137 of 268 students. Based on the findings in the field categorized enough to have an active attitude in conducting experiments, if students find things that are contrary to the results of the experiment, then students respond critically, have high curiosity and never give up. It shows that students like to think critically, find something interesting from physics through the investigation they do. Physics is based on concepts so that in learning abstract things there will be obstacles for students and teachers (Civelek, Ucar, Ustunel, \& Aydin, 2014). By conducting experiments, abstract physics will become easier to understand and demand for students. Students who are still persistent in finding answers to problems that are difficult in investigation, and show students' confidence in their abilities. Students' confidence in their ability to study natural sciences and mathematics largely determines their involvement in investigative activities (Stefan \& Ciomos, 2010). The attitude of students who like to ask after trying to find solutions or answers to these problems, it shows that the curiosity of students is very large, the investigation that he did. Forms of appreciation and support for scientific inquiry from students show that they value the scientific way of gathering evidence, thinking creatively, thinking rationally, responding critically, communicating, and making conclusions, because they face life situations related to science (Bybee, McCrae, \& Laurie, 2009). 
Based on the results of the processing of questionnaire, data in high schools on the indicator of adoption of scientific attitudes showed that the most dominant attitude of good achievement with a percentage of $57.5 \%$ of the total 154 out of 268 students. So it can be said in general that the scientific attitude of students in high schools is classified as positive. The findings in the field which are categorized as good attitude are known that these students like differences of opinion in the classroom. Differences of opinion for example in conducting discussions if there are differences in solving problems can be obtained by several solutions to solve them so that students are not only focused on just one solution. Students who have a good attitude towards attitudes from the scientific can objectively think. Scientific attitude is the ability possessed to behave consistently, rationally and objectively in solving a problem (Olasehinde \& Olatoye, 2014). And students' desire to solve obstacles (problems) that occur in the learning process can improve scientific attitudes. Osborne et al. (2003) said "Scientific attitude is the desire to know and understand, searching for verification and questioning in science." A good scientific attitude will help students to grow good science learning outcomes. Olasehinde and Olatoye (2014) the better the scientific attitude students have the better the students' attitude towards science.

Based on the results of questionnaire data management on indicators of pleasure in physics learning conducted in high schools addressing the most dominant attitude is the Good categorized attitude with a percentage of $43.2 \%$ of the total 116 of 268 students. From the results of these data, it can be said that the attitude of students' enjoyment in learning physics is sufficient or the average is positive. The findings in the field that are categorized as well are known that like to study physics for various reasons, for example because physics has something to do with everyday life, and because physics learning is very pleasant. A good attitude towards pleasure in learning physics, is one of the important elements in physics learning. Good physics learning outcomes are influenced by students' enjoyment of science and pleasure which provides predictive effects in science learning (Ainley, 2011). One positive attitude possessed by students, in the indicator of the pleasure of learning physics can be due to the classroom. Because comfortable classrooms can grow students' skills and increase fun in learning physics (Maharaj-Sharma \& Sharma, 2017). Happy attitude in learning physics that students have will make students enjoy the process of learning physics in the classroom, so students succeed in understanding physics learning.

Based on the results of questionnaire data management on indicators interested in participating in physics learning activities conducted in high schools addressing the most dominant attitudes is categorical attitudes Enough with a percentage of $43.6 \%$ of the total 117 out of 268 students. From the results of these data, it can be said that being interested in participating in physics learning is sufficient or the average is positive. The findings in the field which are categorized as good are known that when physics is about experimentation, students have the pleasure of implementing it, for example, immediately rush to the physics laboratory, sit in front of the lesson, and always ask questions and answer questions when practicing given by the physics teacher. In addition, students are motivated to learn in class because of the comfortable laboratory space that makes students eager to go to the laboratory. Because comfortable classrooms can grow students' skills and increase fun in learning physics (Maharaj-Sharma \& Sharma, 2017).

Based on the results of questionnaire data management on the indicators believe that they have the ability about physics conducted in high school addressing the most dominant attitude is the Good categorized attitude with a percentage of $41.8 \%$ of the total 112 out of 268 students. From the results of these data, it can be said that students believe that they have good abilities about physics or an average positive attitude. The findings in the field that are categorized as good are known that when physics takes place students appear to have no enthusiasm when learning, for example when the teacher asks, the student is willing to answer without being told by the teacher, and the student answers with confidence. Because the student has an inner spirit that causes stimulation to do something. Students have their own willingness to learn physics capable and able to concentrate, which is generated from within themselves (Higgins \& Kruglanski, 2000).

Based on the results of questionnaire data management on indicators enjoying while working on physics tasks performed in high schools addressing the most dominant attitudes is categorical attitudes Enough with a percentage of $38.8 \%$ of a total of 104 out of 268 students. From the results of these data, it can be said that students can enjoy moments when they do enough physics tasks or average positive attitude. The findings in the field which are categorized as good are known that when physics lessons take place students look happy when they are working on questions or physics assignments given by the teacher. Because the student has an inner spirit that causes stimulation to do something. Students who have the will on themselves to learn physics generated from within themselves (Higgins \& Kruglanski, 2000).

Based on the results of the data described previously, it can be seen that there is a relationship between student motivation and attitudes that we can see from the value of the correlation coefficient (r) and sig of the three classes, namely in class $\mathrm{X}$ there is a sig value of 0.24 , which means the sig value obtained smaller than 0.05 means that Ha 
is accepted and there is a relationship between motivation and attitude in class $\mathrm{X}$. If the value of sig $<0.05$ then there is a relationship (M. Gall, J. Gall, \& Borg, 2003). In class X has a value of $r$ or a correlation of 0.3 means that it includes a low positive category. This is in accordance with the level of the relationship, if you get a $\mathrm{r}$ value of 0.31 , then including at the level of low relations (M. Gall, J. Gall, \& Borg, 2003).

Then in class XI there is a probability value of sig of 0.000 , it shows that the sig value is small than 0.05 means Ha is accepted and there is a relationship between motivation and attitude in class XI. If the value of sig $<0.05$ then there is a relationship (Hall, 2003). This is in accordance with the level of relationship, if you get a $r$ value of 0.86 , then including at the level of high relationships (M. Gall, J. Gall, \& Borg, 2003). In class XI has a value of $\mathrm{r}$ or a correlation of 0.86 which belongs to the strong positive category.

Then in class XII has a sig value of 0.000 , it shows that the sig value is small than 0.05 , it means Ha is accepted and there is a relationship between motivation and attitude in class XII. If the value of sig $<0.05$ then there is a relationship (M. Gall, J. Gall, \& Borg, 2003). In class XII has a value of $r$ or a correlation of -0.56 including the negative category while the category is based on M. Gall, J. Gall, and Borg (2003). The purpose of the positive category itself is that there is a unidirectional relationship between the variables $\mathrm{X}$ and $\mathrm{Y}$, namely motivation and attitude, if the motivation rises, then the attitude rises, and if the motivation goes down his attitude also goes down. Then the intent of the negative category itself is the existence of a contradictory relationship between the variables $\mathrm{X}$ and $\mathrm{Y}$, that is, if the motivation raises it is not necessarily the attitude rises, instead it goes down, and if the motivation goes down not necessarily the attitude goes down, but rises. This is in accordance with M. Gall, J. Gall, and Borg (2003) $r=-1$ is a perfect negative correlation, meaning that there is a contradictory relationship between variables $\mathrm{X}$ and $\mathrm{Y}$, if $\mathrm{X}$ rises / high then $\mathrm{Y}$ falls / low, while $\mathrm{r}=1$ is a perfect correlation, which means there is a relationship in the direction of variable $\mathrm{X}$ and variable $\mathrm{Y}$, if $\mathrm{X}$ rises then $\mathrm{Y}$ rises or if $\mathrm{Y}$ drops then $\mathrm{X}$ drops.

Such a biased search may yield an attitude that is somewhat more negative than the attitude that one would report in the absence of motivation (Higgins \& Kruglanski, 2000). This means that the search for something will produce a positive or negative attitude than the attitude reported without motivation. From Higgins and kruglanski's statement, we can conclude that motivation is very important towards attitudes, so motivation and attitudes are interconnected.

The difference between this research and the previous one is that the results of research from Aan Budi Kusuma are only limited to knowing whether there are good or not good physical attitudes in the high school studied. However, this research is different, this research is a continuation of previous research, but the difference is in this study, researchers want to know whether there is a relationship between students' motivation and attitudes towards physics subjects, especially at Senior High School 5, 6, 8 Batanghari, besides that from In terms of the instrument and also from the analysis of the data, it is different from the previous research, and it has been proven that not many have examined the motivation and attitudes of students towards physics subjects and that is the advantage of this research than before. The weakness in this study is the lack of measurement in terms of psychomotor and also cognitive, but this research will be the beginning for research on aspects in terms of psychomotor or in cognitive terms.

\section{References}

Ainley, M., \& Ainley, J. (2011). A cultural perspective on the structure of student interest in science. International Journal of Science Education, 33(1), 51-71. https://doi.org/10.1080/09500693.2010.518640

Astalini, Kurniawan, D. A., Perdana, R., \& Kurniasari, D. (2018). Identification of Student Attitudes toward Physics Learning at Batanghari District High School. The Educational Review, USA, 2(9), 475-484. https://doi.org/10.26855/er.2018.09.003

Astalini, Kurniawan, D. A., Perdana, R., \& Kurniawan, W. (2019). Identification Attitudes of Learners on Physics Subject. EST Journal of Educational Science and Technology, 5(1), 39-48. https://doi.org/10.26858/est.v5i1.8231

Bybee, R., McCrae, B., \& Laurie, R. (2009). PISA 2006: An assessment of scientific literacy. Journal of Research in Science Teaching: The Official Journal of the National Association for Research in Science Teaching, 46(8), 865-883. https://doi.org/10.1002/tea.20333

Civelek, T., Ucar, E., Ustunel, H., \& Aydın, M. K. (2014). Effects of a Haptic Augmented Simulation on K-12 Students' Achievement and their Attitudes towards Physics. Eurasia Journal of Mathematics, Science \& Technology Education, 10(6). https://doi.org/10.12973/eurasia.2014.1122a

Cohen, L., Manion, L., \& Morrison, K. (2007). Research methods in education (London and New York, Routledge). 
Creswell, J. W. (2012). Educational research: Planning, Conducting, and Evaluating.

Darmaji, Kurniawan, D. A., Parasdila, H., Irdianti. (2018). Description of Science Process Skills' Physics Education Students at Jambi University in Temperature and Heat Materials. The Educational Review, USA, 2(9), 485-498. https://doi.org/10.26855/er.2018.09.004

Darmawangsario, R. (2018). Pengembangan Instrumen Sikap Siswa Sekolah Menengah Atas Terhadap Mata Pelajaran Fisika. Jurnal Pendidikan Fisika-Journal of Physics Education, 6(1), 107-114. https://doi.org/10.33627/ge.v2i2.26

Dewati, M. (2015). Pengaruh Model Belajar dan Tingkat Penalaran Formal Terhadap Hasil Belajar Fisika Siswa. Formatif: Jurnal Ilmiah Pendidikan MIPA, 2(3). https://doi.org/10.30998/formatif.v3i2.118

Gall, M. D., Gall, J. P., \& Borg, W. R. (2003). Educational research: An introduction (7th ed.). Upper Saddle River, NJ: Pearson Education, Inc.

Guido, R. M. D. (2013). Attitude and Motivation towards Learning Physics. International Journal of Engineering Research \& Technology, 2(11), 2087-2094.

Hamdu, G., \& Agustina, L. (2011). Pengaruh motivasi belajar siswa terhadap prestasi belajar IPA disekolah dasar. Jurnal penelitian pendidikan, 12(1), 90-96.

Higgins, E. T., \& Kruglanski, A. W. (2000). Motivational Science Social and Personality Perspectives. USA: Taylor \& Francis.

Kurniawan, D. A., Astalini, \& Anggraini, L. (2018). Evaluasi Sikap SMP Terhadap IPA di Kabupaten Muaro Jambi. Jurnal Ilmiah Didaktika: Media Ilmiah Pendidikan dan Pengajaran, 19(1), 123-139.

Lederman, N. G., Lederman, J. S., \& Antink, A. (2013). Nature of science and scientific inquiry as contexts for the learning of science and achievement of scientific literacy. International Journal of Education in Mathematics, Science and Technology, 1(3), 138-147.

Lucardie, D. (2014). The impact of fun and enjoyment on adult's learning. Procedia-Social and Behavioral Sciences, 142, 439-446. https://doi.org/10.1016/j.sbspro.2014.07.696

Maharaj-Sharma, R., \& Sharma, A. (2017). USING ICT IN SECONDARY SCHOOL SCIENCE TEACHING-WHAT STUDENTS AND TEACHERS IN TRINIDAD AND TOBAGO SAY? European Journal of Education Studies.

Manasia, L. (2015). Enjoyment of learning in upper secondary education. An exploratory research. Procedia-Social and Behavioral Sciences, 180, 639-646. https://doi.org/10.1016/j.sbspro.2015.02.172

Moeed, A. (2013). Science Investigation That Best Supports Student Learning: Teachers' Understanding of Science Investigation. International Journal of Environmental and Science Education, 8(4), 537-559. https://doi.org/10.12973/ijese.2013.218a

Mukhopadhyay, R. (2014). Scientific attitude-some psychometric considerations. IOSR Journal of Humanities and Social Science (IOSR-JHSS) OSR-JHSS, 19, 98-100. https://doi.org/10.9790/0837-191798100

Olasehinde, K. J., \& Olatoye, R. A. (2014). Scientific attitude, attitude to science and science achievement of senior secondary school students in Katsina State, Nigeria. Journal of Educational and Social Research, 4(1), 445. https://doi.org/10.5901/jesr.2014.v4n1p445

Osman, K., Iksan, Z. H., \& Halim, L. (2007). Sikap terhadap sains dan sikap saintifik di kalangan pelajar sains. $\begin{array}{lllll}\text { JURNAL PENDIDIKAN, } & 32, & 39-60 . & \text { Retrieved } & \text { from }\end{array}$ http://ejournals.ukm.my/jpend/article/viewFile/14717/4471

Prihatiningtyas, S., Prastowo, T., \& Jatmiko, B. (2013). Imlementasi Simulasi PhET dan Kit Sederhana untuk Mengajarkan Keterampilan Psikomotor Siswa pada Pokok Bahasan Alat Optik. Jurnal Pendidikan IPA Indonesia, 2(1).

Rijal, S., \& Bachtiar, S. (2015). Hubungan antara Sikap, Kemandirian Belajar, dan Gaya Belajar dengan Hasil Belajar Kognitif Siswa. Jurnal Bioedukatika, 3(2), 15-20. https://doi.org/10.26555/bioedukatika.v3i2.4149

Santoso, S. (2013). Pengaruh Model Pembelajaran Kolaboratifdan Motivasi Belajar Terhadap Peningkatan Hasil Belajar Fisika Siswa Kelas X SMAN 1 Purwantoro Wonogiri, Jawa Tengah. Berkala Fisika Indonesia, 5(1), 15-19

Stefan, M., \& Ciomos, F. (2010). The 8th and 9th Grades Students' Attitude towards Teaching and Learning Physics. Acta Didactica Napocensia, 3(3), 7-14. 
Sudibyo, E., Jatmiko, B., Widodo, W. (2016). Pengembangan Instrument Motivasi Belajar Fisika: Angket. Jurnal Penelitian Pedidikan IPA, 1(1), 13-21. https://doi.org/10.26740/jppipa.v1n1.p13-21

Trumper, R. (2006). Factors affecting junior high school students' interest in physics. Journal of Science Education and Technology, 15(1), 47-58. https://doi.org/10.1007/s10956-006-0355-6

Zhang, L., \& Han, Z. (2008). A Teaching Attitude Adjusting Model for College Teachers Based on Attitude Theories. International Education Studies, 1(1), 64-68. https://doi.org/10.5539/ies.v1n1p64

\section{Copyrights}

Copyright for this article is retained by the author(s), with first publication rights granted to the journal.

This is an open-access article distributed under the terms and conditions of the Creative Commons Attribution license (http://creativecommons.org/licenses/by/4.0/). 